EESTI NSV TEADUSTE AKADEEMIA TOIMETISED. 19. KÖIDE

KEEMIA * GEOLOOGIA. 1970, Nr. 2

ИЗВЕСТИЯ АКАДЕМИИ НАУК ЭСТОНСКОН ССР. ТОМ 19

Химия * ГЕОЛОГИЯ. 1970, № 2

ХЕЛИ ВОOРЕ

\title{
РЕАКЦИОННАЯ СПОСОБНОСТЬ РАЗВЕТВЛЕННЫХ ФЕНИЛОКТАНОВ В РЕАКЦИЯХ АЛКИЛИРОВАНИЯ С ХЛОРИСТЫМ АЛЮМИНИЕМ
}

\section{СООБЩЕНИЕ 1}

Реакционная способность монозамещенных бензола в реакцнях алкилирования зависит от длины цепи и строения замещающего радикала. В предыдущих работах было показано, что реакционная способность. н-октилбензола при алкилировании его 1-октеном и 1-пентеном ниже, чем у бензола $\left[{ }^{1-3}\right]$. При этом реакционная способность тем выше, чем короче углеводородная цепь алкилирующего алкена. С. Файнгольд и Г. Степанова $\left[{ }^{4}\right]$ определяли реакционную способность н-октилбензола в реакции алкилирования н-октенами с различным положением двойной связи, причем установили ее независимость от положения двойной связи алкилирующего бензол алкена. Это объясняется тем, что независимо от местоположения двойной связи алкилирующего бензол алкена всегда получается равновесная смесь монофенилалканов, отличающихся местом присоединения фенила в алкильной цепи. В литературе отсутствуют данные о влиянии на реакционную способность разветвленности алкилирующего агента.

Целью настоящей работы было изучение влияния разветвленности алкильного радикала высших гомологов бензола и цепи алкилирующего алікена на реакционную способность фенилалканов. Для этого определялась реакционная способность изооктилбензола при алкилировании его изооктеном в присутствии хлористого алюминия в нитробензоле.

В данном случае разветвленность алкильного радикала и алкилирующего алкена минимальна, а длина основной алкильной цепи на одну метильную группу меньше, чем у н-октилбензола и поэтому можно ожидать незначительное влияние на реакционную способность фенилалкана.

Судя по литературным данным, различие в строении алкилирующего бензол алкена оказывает влияние на выход продуктов реакции [5]. Разветвленные алкены по сравнению с прямоцепочными в большей мере подвергаются полимеризации, а продукты их присоединения более склонны к дезалкилированию и диспропорции. Применение катализатора в растворе нитрометана или нитробензола уменьшает роль побочных реакций, но не устраняет их [6].

Для определения реакционной способности изооктилбензола изучался:

1) состав продуктов совместного алкилирования фенилизооктана в. смеси с бензолом или этилбензолом и

2) состав продуктов последовательного алкнлирования бензола изооктеном (метод Плюснина $\left.\left[{ }^{5}\right]\right)$. 
В настоящем сообщении излагаются результаты исследования реакционной способности по первому способу. Реакционная способность фенилизооктана вычислялась по уравнению $[7,8]$ :

$$
\frac{k_{\text {фенилизооктана }}}{k_{\text {бензола }}}=\lg \frac{y}{y_{i}} / \lg \frac{x}{x_{\iota}},
$$

где $k_{\text {фенилизоокана }}$ - константа скорости реакции присоединения изооктена к фенилизооктану;

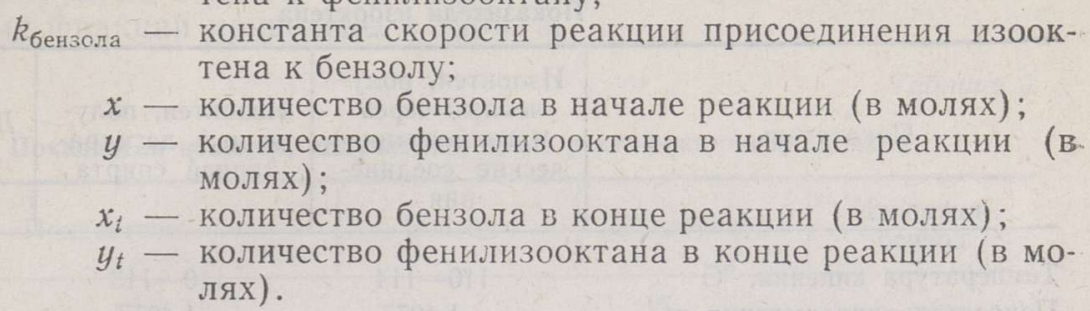

Так как в конечной реакционной смеси невозможно дифференцировать содержанне фенилизооктана, введенного в начале реакции и полученного в ходе реакции, то реакционная способность определялась в двух стадиях. Сначала определялась реакционная способность этилбензола в смеси с бензолом при алкилировании его изооктеном, а затем относительная скорость реакции алкилирования фенилизооктана в смеси с этилбензолом. По этим данным была рассчитана реакционная способность фенилизооктана.

\section{Экспериментальная часть}

Получение исходных веществ. Исходными веществами служили продажные «хч»бензол, «хч»этилбензол, «хч»нитробензол и синтезированные нами изооктан и фенилизооктан. Их показатели приведены в табл. 1.

Таблица 1

Показатели исходных веществ

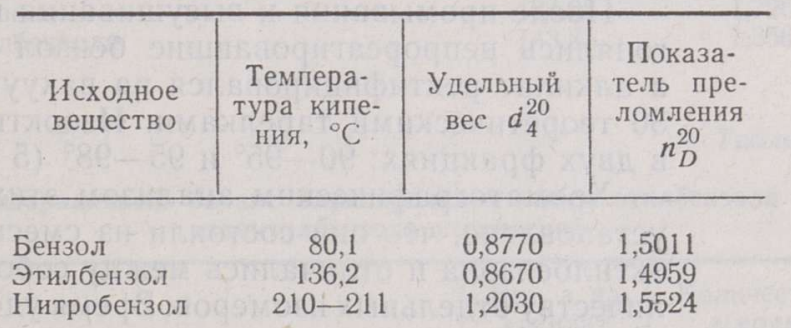

Изооктен синтезировался через магнийорганические соединения из. нзоамилбромида и аллилбромида по реакции [9]:

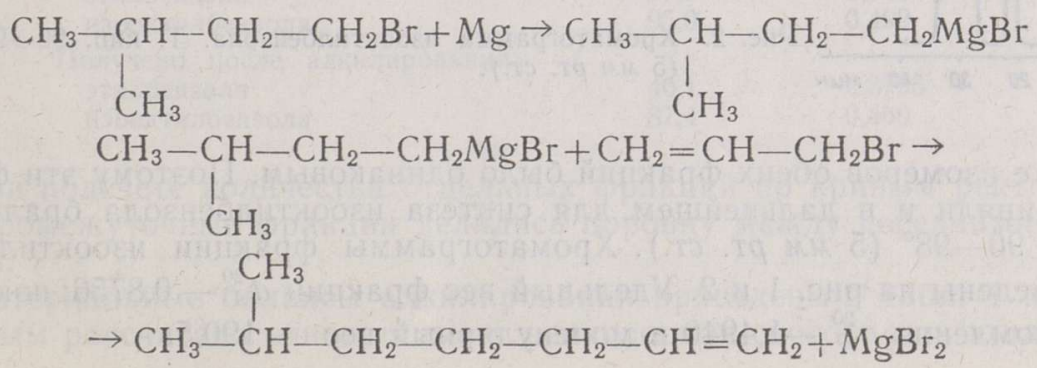


и дегидратацией изооктилового спирта через промежуточную стадию получения сложного эфира со стеариновой кислотой [3].

После промывания и высушивания полученный изооктен ректифицировался на колонке с 30 теоретическими тарелками и выделялась целевая фракщия $110-114^{\circ} \mathrm{C}$. Полученные различными способами фракщии имели одинаковые показатели и содержали $90 \%$ изооктена. Показатели изосктена приведены в табл. 2.

Показатели изооктена

Таблица '2

\begin{tabular}{c|c|c|c}
\hline Показатель & $\begin{array}{c}\text { Изооктен, полу- } \\
\text { ченный через } \\
\text { магнийоргани- } \\
\text { ческие соедин- } \\
\text { ния }\end{array}$ & $\begin{array}{c}\text { Изоокен, полу- } \\
\text { тацией дегидра- }\end{array}$ & $\begin{array}{c}\text { Данные лите- } \\
\text { ратуры }\end{array}$ \\
\hline
\end{tabular}

Температура кипения, `C Показатель преломления $n_{D}^{20}$

Бромное число

Содержание олефина по бромному числу

$\begin{array}{cc}110-114 & 110-113 \\ 1,4077 & 1,4077 \\ 128 & 128,3 \\ 90,0 & 90,3\end{array}$

113

Фенилизооктан был получен алкилированием бензола, синтезированного изооктеном в присутствии 10\%-ного раствора хлористого алюминия в нитробензоле. Количество хлористого алюминия на алкен составляло
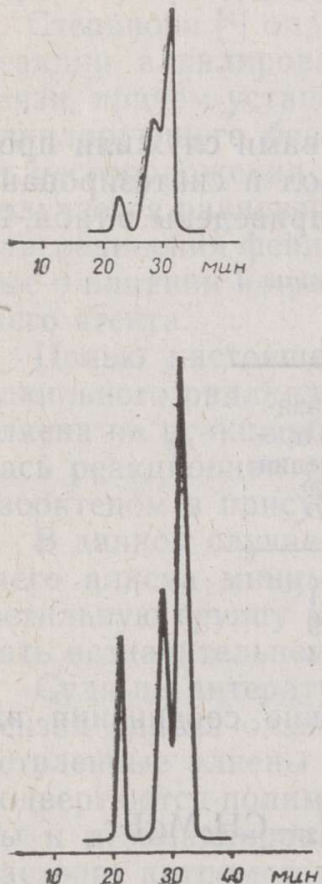

15 вес. \%. Температура реакции $35^{\circ}$, молярное соотношение алкена и бензола $1: 8$, скорость подачи алкена 0,25 моль/ч.

Рис. 1. Хроматограмма изооктилбензола. Т. кип. $95-98^{\circ}$ (5 us pT. CT.).

После промывания и высушивания из алкнлата отгонялись непрореагировавшие бензол и нитробензол, а алкилат ректифицировался на вакуумной колонке с 30 теоретическими тарелками. Изооктилбензол брали в двух фракциях: $90-95^{\circ}$ и $95-98^{\circ}$ (5 мм рт. ст.).

Хроматографическим анализом этих двух фракций установлено, что они состояли из смеси изомеров изооктилбензола и отличались между собой только по количеству отдельных изомеров. Время удерживания в ко-

Рис. 2. Хроматограмма изооктилбензола. Т. кип. $90-95^{\circ}$ (5 м.м рт. ст.).

лонке изомеров обеих фракций было одинаковым. Поэтому эти фракции соединяли и в дальнейшем для синтеза изооктилбензола брали фракцию $90-98^{\circ}$ (5 мм рт. ст.). Хроматограммы фракции изооктилбензола приведены на рис. 1 и 2. Удельный вес фракции $d_{4}^{20}-0,8756$; показатель преломления $n_{D}^{20}-1,4940$ и молекулярный вес $-190,5$. 
Определение реакционной способности фенилизооктана. Алкилирование смесей бензол-этилбензол и этилбензол-изооктилбензол изооктеном проводилось в присутствии $10 \%$-ного раствора хлористого алюминия в нитробензоле. Қоличество катализатора - 15 вес. \% на алкен; молярное соотношение бензола и этилбензола - $1: 1$, алкена и ароматических углеводородов - $1: 4$; температура реакции $35^{\circ}$; скорость прибавления алкена - 0,1 моль/ч. Продукты реакции разделялись ректификацией на вакуумной колонке с 30 теорегическими тарелками. Показатели полученных фракций приведены в табл. 3.

Таблица 3

Показатели веществ, полученных после ректификации алкилатов

\begin{tabular}{l|l|l|l}
\hline Показатели & Бензол & Этилбензол & $\begin{array}{c}\text { Нзооктил- } \\
\text { бензол }\end{array}$ \\
\hline
\end{tabular}

Предел кипения, ${ }^{\circ} \mathrm{C}$

Удельный вес $d_{4}^{20}$

$\begin{array}{ccc}80-81 & 136-136,5 & 247-260 \\ 0,877-0,878 & 0,866-0,870 & 0,8750-0,879 \\ 1,5002-1,501 & 1,4935-1,4961 & 1,4931-1,495 \\ 0 & 0 & 0 \\ 78,5 & 106,4 & 191,4\end{array}$

Таблица 4

Показатель преломления $n_{D}^{20}$

Бромное число

Молекулярный вес

78,5

106,4

191,4

Материальный баланс алкилирования смеси бензола и этилбензола изооктеном

\begin{tabular}{l|c|c}
\hline & $\begin{array}{c}\text { Вес, 2 на } \\
\text { алкилат }\end{array}$ & $\begin{array}{c}\text { Количество } \\
\text { гјмоль }\end{array}$ \\
\hline
\end{tabular}

Взято для алкилирования:

$\begin{array}{lll}\text { эензола } & 156,0 & 2,0 \\ \text { этилбензола } & 212,0 & 2,0 \\ \text { олучено после алкилирования: } & 134,05 & 1,720 \\ \text { бензола } & 143,85 & 1,356 \\ \text { этилбензола } & \end{array}$

Таблица

Материальный баланс алкилирования смеси этилбензола и изооктилбензола изооктеном

\begin{tabular}{l|c|c}
\hline Вес, г на & $\begin{array}{c}\text { Количество } \\
\text { гімоль }\end{array}$ \\
\hline
\end{tabular}

$\begin{array}{lll}\text { Взято для алкилирования: } & & \\ \text { этилбензола } & 57,8 & 0,545 \\ \text { изооктилбензола } & 95,0 & 0,499 \\ \text { Получено после алкилирования: } & & \\ \text { этилбензола } & 40,1 & 0,3795 \\ \text { изооктилбензола } & 87,4 & 0,460\end{array}$

При подсчете количества отдельных фракций по кривым ректификации промежуточные фракции делились порсвну между соседними фракциями.

Материальные балансы алкилирования приведены в табл. 4 и 5 , по которым рассчитана относительная реакционная способность этилбензо- 
ла (по сравнению с бензолом) и изооктилбензола (по сравнению с этилбензолом).

$$
\begin{aligned}
k_{1} & =k_{\text {этилбензола }}=2,60, \\
k_{11} & =\frac{k_{\text {фенилизооктана }}}{k_{\text {этнлбензола }}}=0,227 .
\end{aligned}
$$

Относительная скорость алкилирования фенилизооктана по сравнению с бензолом, т. е. его реакционная способность

$$
k_{\text {фенилизооктана }}=k_{1} \cdot k_{\mathrm{II}}=0,59 .
$$

\section{Выводы}

1. Определена реакционная способность фенилизооктана при алкилировании его изооктеном в присутствии хлористого алюминия методом совместного алкилирования. Реакционная способность фенилизооктана по отношению к реакционной способностй бензола составляет 0,59 .

2. Разветвление боковой цепи фенилоктанов несколько уменьшает их реакционную способность при алкилировании.

\section{ЛИ ТЕРАТ У РА}

1. Ф а й н гольд С. И., В оо ре Х. Ю., Изв. АН ЭССР, Сер. фнз.-матем. и техн. наук, $12,100(1963)$.

2. $Ф$ айнгольд С. И., В ооре Х. Ю., ЖПХ, 36, 2527 (1963).

3. В о ор е Х. Ю., Алкилирование ароматических углеводородов моноолефинами. Канд. дисс., Таллин, 1964.

4. С те п а н ов а Г. Г., Ф айнгольд С. И., Изв. АН ЭССР, Хим. Геол., 17, 69 (1969).

5. Пл юс н и н В. Г., Химическая переработка нефтяных углеводородов, М., 1956, с. 306.

6. S a n ford R. A., K ov a ch S. M., Industr. and Engng Chem., 40, 1455 (1959).

7. Л е бедев Н. Н., Ба тадж и И. И., Научн. докл. высших школ. Хим. и хим. технол., № 1, 104 (1958).

8. In gold C. K., J. Chem. Soc., No. 8, 1931 (1959).

9. Ko marevski S. a. o., J. Am. Chem. Soc., 67, 557 (1945).
Ннститут химии
Академии наук Әстонской ССР
Поступила в редакцию 11/VI 1969

\section{HELI VOORE}

\section{HARGNENUD AHELAGA FENUULOKTAANIDE REAKTSIOONIVŌIME MÄARAMINE ALKÜÜLIMISEL $\mathrm{AICl}_{3}$ MANULUSEL. 1}

Nn. koosalküülimise meetodi abił uuriti isooktüülbenseeni reaktsioonivõimet tema. alküülimisel isookteeniga $\mathrm{AlCl}_{3}$ manulusel. Alküüliti kahes etapis: esmalt isooktüülbenseeni segus benseeniga ja siis etüülbenseeniga. Alküülimine toimus nitrobenseeni lahuses, kusjuures produktide saagised määrati rektifitseerimise teel. Etüülbenseeni reaktsioonivõime oli $2,60 \mathrm{ja}$ isooktüülbenseeni reageerimiskiirus etüülbenseeniga 0,227 . Isooktüülbenseeni reaktsioonivõime oli 0,59 .

\section{HELI VOORE}

\section{DETERMINATION OF THE REACTIVITY OF PHENYL-OCTANES WITH A LOOSE: CHAIN AT ALKYLATION IN THE PRESENCE OF $\mathrm{AlCl}_{3}$. 1}

With the help of the so-called co-alkylation method, a study was made of the reactivity of isooctyl-benzol at its alkylation with isooctene in the presence of $\mathrm{AlCl}_{3}$. The alkylation of isooctyl-benzol was effected in two stages: firstly, in a mixture with benzol, and secondly - with ethyl-benzol.

Alkylation proceeded in the solution of nitrobenzol, the yields of products being determined by rectification. The reactivity of ethyl-benzol was stated to be 2.60 , and reaction speed of isooctyl-benzol with ethyl-benzol being 0.227 . The reactivity of isooctylbenzol was 0.59 . 